\title{
WOMEN IN THE CLASS OF 1979: THIRTEEN YEARS LATER
}

\author{
JUNE ROSS, DONNA SHELLEY, LINDA RICHARDSON, \\ JEAN COUTTS, MARIE GORDON, ELIZABETH MACINNIS, \\ DORIS WILSON and ELIZABETH JOHNSON*
}

In a more informal mamner from that of Brockman. the authors survey and explore the various experiences that they themselves, along with other female colleagues. have had as nomen in the ficld of laur. The arricle focuse's on incide'nts of gender discrimination witnessed by the women who sraduated from the University of Alherta law school in 1979. Thus, the survey acts as a local comtribution to that growing body of literature which reveals the female experience in law and exposes the reality of gender discrimination within the profession.
Sw in mode moins formel que Brockman. les auteures passent en revue et examinent les diverses expéricnces qu'elles-mêmes et d'autres femmes ont vécues dans le domaine du droit. L'article s'attache atux incidents de discrimination dom ont été témoin les cencliantes de la faculté de droit de luniversité de' l'Alberta qui ont obtenu leur diplome en 1979. Ainsi, cette enquête constitue une contribution locale à un fonds documentaire qui révèle l'expérience féminine en droit et qui expose la réalité de la discrimination fondée sur le sexe dans la profession.

\section{TABLE OF CONTENTS}

I. INTRODUCTION $\ldots \ldots \ldots \ldots \ldots \ldots \ldots \ldots \ldots \ldots \ldots 43$

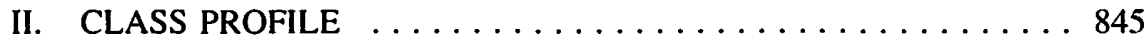

III. GENDER BIAS IN THE PROFESSION $\ldots \ldots \ldots \ldots \ldots \ldots \ldots 845$

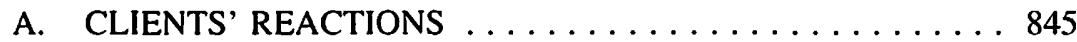

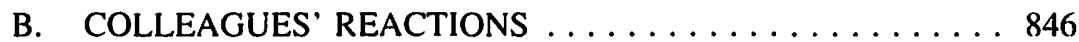



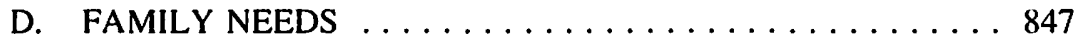

E. OTHER PERSPECTIVES $\ldots \ldots \ldots \ldots \ldots \ldots \ldots \ldots . \ldots 848$

IV. ACHIEVEMENTS AND SATISFACTION $\ldots \ldots \ldots \ldots \ldots \ldots 848$

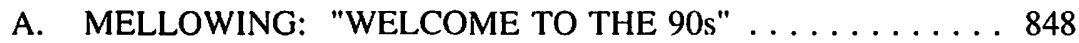

B. PRIVATE PRACTICE VS.

ALTERNATIVE LEGAL CAREERS $\ldots \ldots \ldots \ldots \ldots . \ldots 849$

C. THE BOTTOM LINE $\ldots \ldots \ldots \ldots \ldots \ldots \ldots \ldots \ldots \ldots$

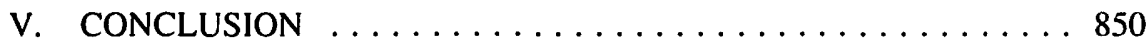

\section{INTRODUCTION}

This is an article about the women who graduated from the University of Alberta law school in 1979. It relates their experiences with gender discrimination in the legal profession and gives their reflections on their legal careers to date. Thirteen years ago, most of us started our careers with the perception that we were equal to our male colleagues. While we anticipated a few unfortunate exceptions or incidents, we expected that generally we would be treated as equals and would have an equal opportunity to "succeed." Many of us have reevaluated those expectations and the assumptions

The first author is an Assistant Professor of Law at the University of Alberta; the remaining authors practice law in Edmonton. Alberta. 
underlying them, including the nature of "success." This is a joint presentation of our experiences and insights.

The authors of this article are more aptly described as compilers and editors. The real authors are the members of the class who provided their own thoughts on these issues, to some extent during a series of meetings but primarily in individual interviews or through individually written comments. These interviews and comments were structured around a list of questions.' We have tried to pull together the varied information and ideas provided by 28 of the 41 female members of our class.

We hope that this will be of interest to women contemplating or beginning legal careers. We also hope it will be viewed as a small contribution to the growing body of literature described in Joan Brockman's paper on gender bias in the legal profession.' Many of the experiences described here are repeated with slight variations in the surveys that she performed in Alberta and British Columbia ${ }^{3}$ and in a similar Ontario survey. ${ }^{+}$ There are, however, some differences in the focus. The median year of call of the 600 Alberta women who responded to the general survey was $1985 . .^{5}$ Our profile deals with a much smaller group admitted to the bar five years earlier. Of the women involved in the larger survey, only $52.7 \%$ had children. ${ }^{\circ}$ Of our class, the great majority of us have young children. Thus, we present a different and more homogenous profile; we are a group of women who have been admitted to the bar for a long enough period to have established careers and who are almost all dealing with the competing claims of those careers and our young families. Another focus that may make this piece relevant to women interested in practising law in the Edmonton area is that our class largely articled and practises in Edmonton, so that the related experiences are generally local. Finally,

1. The questions are listed below:

1. What are you doing now professionally?

2. What are you doing in terms of community involvement?

3. What are your personal or family circumstances?

4. How would you define success today? Has you definition of success changed since graduation?

5. Are you happy with you professional life today? Does it meet the ambitions and expectations you had leaving law school? Did your ambitions and expectations change?

6. How has being a woman made a difference in your professional life?

7. If you could make changes in your professional life now, what would they be?

J. Brockman, "Bias in the Legal Profession: Perceptions and Experiences" (1992) 30 Alta L. Rev. 747 [hereinafter Bias].

J. Brockman, Encoumering Barriers andlor Moving On: A Survey of Former Members of the Law Society of British Columbia (A Report Prepared for the Law Socicty of British Columbia's Subcommittee on Women in the Legal Profession, August, 1990) (hereinafter Encoumtering Barriers] and J. Brockman, Identifying the Barriers: A survey of Members of the Law Society of British Columbia (A Report Prepared for the Law Society of British Columbia's Subcommittee on Women in the Legal Profession. April. 1991). The reports are found as Appendices 1 and 2 to the Report of the Women in the Legal Profession Subcorumittec of the Law Society of British Columbia, Women in the Legal Profession (September 1991).

t. Law Society of Upper Canada: Transitions in the Ontario Legal Profession; A Survey of Lawyers Called to the Bar Between 1975 and 1990 (May 1991) |hereinafter Transitions].

5. Bias, supra, note 2 at 752.

6. Ibid. at 754 . 
we explore not only the issues of gender bias in the profession, but also the overall degree of satisfaction or perceived success of women in terms of their professional achievements.

\section{CLASS PROFILE}

As indicated above, 41 women graduated in 1979 from the Faculty of Law at the University of Alberta. We were able to collect written or verbal comments from 28 of them. Limited information was obtained about another 10 from personal histories provided during our class reunions or by "word of mouth."

We were able to determine where 36 women articled. Thirteen articled with medium or large firms, 12 in Edmonton and one in Calgary. Seventeen articled with small firms, mostly in Edmonton, but also in smaller centres in Alberta, and one in the North West Territories. Six articled with government in Edmonton. Two of our classmates never articled.

For those who did article, we also determined where they are working now. Eight are employed by medium to large firms, 7 in Edmonton and one in Vancouver. Of these, 6 are partners in the firms. One of the women working as an associate is working parttime.

Twelve of our classmates are working in either small firms or associations, or as single practitioners. Nine are working in Edmonton, one is in a smaller centre in Alberta, and 2 are out of province. Of these, one is working part-time. Ten are working with the municipal or provincial governments in Edmonton with three of them working on a parttime basis. Two are counsel to private corporations in Edmonton, one is teaching law, one is a public school board trustee, and one has retired.

Of the 28 women who provided comments, 20 are married, 7 are single (including both those who never married and those who have divorced) and one is separated. Twenty-five of the 28 women have children. It is significant that of the 25 with children, only three have children over the age of 10 . Most of the women have two children, a few have either one or three, and one is anticipating the birth of her fourth child. Not surprisingly, the pressure of combining a legal career with the raising of a young family is a strong theme for our class.

\section{GENDER BIAS IN THE PROFESSION}

How has being a woman made a difference? Almost without exception the women in our class cite areas where their gender has affected their career.

\section{A. CLIENTS' REACTIONS}

Some women cite a pronounced difference in treatment by clients in private practice, especially in the earlier part of their careers. They feel that they were not taken as seriously as a man would have been and that there was an initial barrier or "something 
extra" that had to be proved before they could go on with their real work. One client told a classmate that he would not even put his house in joint tenancy with a woman: how could he possibly take advice from a woman lawyer? Another classmate who practices quite a bit of criminal law feels that this differential treatment continues even now. In an initial interview with a client, it is necessary for her to convey, to a greater degree than a man would have to, a level of professional competence, since the client is more likely to assume that a man has the required competence.

Business promotion activities are a problem for some women, as they tend to be maleoriented. One classmate adds that these activities, already difficult because of her gender, are made even more so by her single status. Some classmates feel that an exclusion from the golf game or similar client promotion activities also excluded them from practice in particular areas, such as corporate/commercial or bankruptcy law.

\section{B. COLlEAGUES' REACTIONS}

Some of the women relay the experience of having senior lawyers be occasionally patronizing and expecting a woman lawyer to play supportive, assisting, second-counsel roles. Others comment that they tended to be given particular types of files, such as matrimonial.

Being a woman had a negative influence in practising criminal law for one member of our class who found few women in that field, especially in the defence counsel role. She was shocked to be treated differently by judges, police and other professionals. She eventually left private practice to work as corporate in-house counsel. Another classmate recalls an incident in which a provincial court judge commented that she was "talking on and on...just like a woman" when she was trying to make a complex constitutional argument. He later apologized.

The numcrous examples of sexist treatment were sometimes overt (being called "dearie" or "good girl" by male lawyers) and sometimes covert (being ignored at all male meetings). One classmate wonders if being a woman cost her a promotion in government.

Most of the specific instances of overt differential treatment occurred earlier in our careers. Only one woman, who works in a particularly male-dominated area of government practice, says that the problems continue:

\footnotetext{
Being a woman has often been trying as I have always been the only woman in the room so I am "fair game" for sexist jokes and other comments... I have been accused of being a neglectful mother... I have had men commiserate with me...because I had to work... I have been utterly ignored because it was assumed my presence at a meeting was to take notes and pour coffee. In a word, yes, it has made a big difference... After 10 years, I still have to prove myself to each new person. People assume I report to the man who works for me because he "should" be the boss.
}

However, for most of us, the problem of overt differential treatment seems to have abated over the 12 years in practice. We can speculate on why this is - this form of discrimination may be disappearing or seniority may provide some protection against such 
treatment. Perhaps those members of our class who faced the worst barriers have moved to more compatible work environments or areas of practice.

\title{
C. THE PREGNANT LAWYER
}

Many of our classmates found that gender discrimination by clients and colleagues worsened during their pregnancies. One recalls that when she was pregnant with her first child, a lawyer told her she had taken away a job from a man and that she was wasting taxpayers' money (that paid for her education) if she were going to work part-time. That lawyer is now a provincial court judge. A Queen's Bench Justice, while speaking to one classmate about a pregnant female lawyer of his acquaintance, automatically assumed that she would cease practising (and bemoaned the loss of good potential).

Several of the women note pressures surrounding the taking of maternity leave. One classmate took a minimum maternity leave of 6 weeks in order to "prove the sceptics wrong" about her willingness to return to work following the birth of her baby. In hindsight, she says. it was detrimental to her physical health, and she now regrets returning to work so early for what she sees as "inappropriate reasons." The worst experience related to maternity leave was:

\begin{abstract}
After the birth of my first child. I had planned a 4 month maternity leave after which I was to return to private practice with a firm I had been with for over 3 years. I was asked to give assurances about my return and these were provided. My last few months of pregnancy were a virtual nightmare of court applications and trials and I ended up working past my due dalc. While I was on leave the managing partner spent the time "second guessing" as many of my files as he could get and generally working on the other partners to make a case for my termination. My termination was communicated less than a month before I was to return to work. With a new baby I didn't have the energy to re-establish myself in a new firm and it took me 4 and $1 / 2$ years to get back into practice.
\end{abstract}

\section{FAMILY NEEDS}

Almost unanimously, members of our class feel that having children has radically changed their lives and has affected their careers. "I did not expect that my other [family] commitments would so significantly affect the time and energy which I have available to practice law" says one. As a class, it has meant that we have interrupted our careers and that we are for the most part unable and/or unwilling to commit to constant evening and weekend work.

Over and over again, the concern is expressed that women who have families find themselves in the role of being primary caregivers to children and primarily responsible for household duties:

...like most women. I do perceive that my share of child care responsibilities is greater than my husband's. Especially if the children are sick, or having difficulty adjusting to new activities or people. or are simply unhappy for some reason. 1 feel primarily responsible for helping them, making changes, taking extra time to sort things out. So it is not just that in a normal day I spend more time al home 
(which I do) but that in abnormal circumstances...it is my career, not my husband's, that has to accommodate the problems. Why mine?

"Prejudice began when I had a child" says one woman. She recalls that once she had a child, there was no ability to customize her work hours or to work part time. At that point she was put to a choice in her career which has resulted in her practising part time out of her home rather than in association with other lawyers.

\section{E. OTHER PERSPECTIVES}

On the other hand, some women have managed to achieve a more egalitarian relationship at home involving child care and housework duties. This has enabled one to succeed in a larger firm setting as a partner and major earner in the family. One classmate says that being a parent had a huge impact on her career choices, but that she has not been affected more than a man making similar choices. A few comment that men practising law feel the same pressures from family commitments and "seem to share the perplexities and dilemmas which we have faced." Men are perceived as less likely to reduce their work load to accommodate family, but this may be "due to expectations of other lawyers, clients and social pressures."

Some of our classmates, with children who have been grown up for some time, do not feel that being a woman has made any real difference. For one of our classmates, law represents her sixth career. She feels that she has been "around the block" and has never let a man stand in her way. She feels men and women are equal "from the neck up."

\section{ACHIEVEMENTS AND SATISFACTION}

\section{A. MELLOWING: "WELCOME TO THE 90s"}

Do you feel successful? The 28 women who discussed this used various definitions of success. While many recognize that the more traditional definition, based on success in one's career, is still accepted in many firms, almost all favour the use of a broader definition with a focus on balancing work, family and community roles. Several say that it depends on what measuring stick is being used. If the measuring stick is "being a senior partner in a large firm with a large clientele; being recognized by peers as having a high degree of competence; having a long and impressive resume...and having attained positions of influence in professional and other organizations," clearly most cannot say they have achieved that kind of success. Some do feel they are making reasonable progress toward such a goal which is arguably all that can be expected at this point. When asked whether she thinks she is "successful," one woman says that "...a simple 'yes' answer implies that there is nothing left to achieve. It seems to me to be an assessment which is made at the end, looking back."

Most classmates describe success in terms of living a balanced life and enjoying what they are doing, rather than having to make a lot of money to feel successful. Nonetheless, comfortable financial circumstances allow many to pay for full-time help at home and other advantages that allow them to achieve a degree of balance in their lives. Being 
recognized by peers or superiors for competence in their work, having happy, healthy children, working reasonable hours, and having the time to pursue other interests besides a career are some of the elements deemed to be important in defining success. There is also recognition that the emphasis now being placed on the more personal aspects of life is, in the case of parents of young children, a self-imposed and time-limited emphasis that will likely change in the future. The common thread that is clearly highlighted in this commentary about success is that success is not linked solely to achievements in the practice of law.

When talking in terms of general satisfaction with their lives, rather than the arguably narrower term "success," all 28 express general satisfaction, with a few minor qualifications. Several indicate that they are still struggling to achieve a reasonable balance between work and family. Others say that, although they can balance work and family, there is little or no time left for themselves or for pursuing extracurricular professional activities. While 19 of our classmates indicate that they are involved in volunteer organizations in the community, for 12 of them, this is restricted to activities related to their children's sporting, school or church programs. Only 10 are involved in extracurricular professional associations, and of these, only 6 have young children. On the "wish list" are such things as taking more holidays, being able to work more flexible hours, working at home and having summers off.

Women without young families are also trying to achieve a balance in their lives to offset the major priority and time commitment they have given to their practices. One single woman without a family says that she feels that women have more "chores" in their private lives, even without children, and get less support in their careers than men. Another classmate, also single and without dependants, who is a partner in a large firm, is among the few to claim that her ambitions have not changed much since law school and that she has achieved her own definition of career success as a "partner with a firm of the reputation of [firm name] and practising in an area of the law that I enjoy." But she, too, reflects on the costs involved:

....achieving my goals with respect to my professional life has been at the sacrifice of other areas of my life and particularly what one would describe as quality of life. I have made work a priority in my life and have at various periods of time felt a need to reassess that prioritization.

\section{B. PRIVATE PRACTICE VS. ALTERNATIVE LEGAL CAREERS}

All of the women who chose legal careers outside of private practice state that they did so to achieve a better balance in their lives. They feel that their career choices have contributed to their overall satisfaction with life. One who has made such a change comments that she has seen many women in our class opt for work other than private practice. She senses that they may be happier because of these choices than classmates in large private firms. Further, three of the 10 women in government positions are working part-time, again to accommodate family needs.

The women who remain in private practice, with smaller or larger firms, are also generally satisfied and working to achieve a balance between work and family. However, 
only two of the 20 in private practice are working part-time. One comments that while her firm is amenable to part-time arrangements:

...I believe that those people who have requested arrangements of this nature have been perceived, and consequently treated. differently as a result of their requests. I believe the perception that results from making the request (whether or not it's implemented) is that the person is not as committed to the practice of law, not as serious about her career and not as valuable to the firm.

One of our classmates who was a partner in a large firm left because the firm would not accommodate a part-time work arrangement. She subsequently secured such an arrangement at another firm.

Even among those working full-time in private practice, commitment to family can be perceived as a drawback. One woman says:

There is a tendency in a private firm. especially among women, to downplay home-related activities. There is a feeling that such activities reflect a lack of commitment to the practice of law and to the firm. In my experience this attitude is very subtle and difficult to pin down, but it is there.

I think this ethos was far more prevalent among the women who went before us; witness the "return-towork-after-baby sweepstakes". I think that women of our "vintage" have tried to bring a more balanced approach to meshing home and work, but there is still a lot of pressure and the consequent guilt.

On this point, as on many others, there is certainly not unanimity. Some classmates in private practice, including with mid-size or larger firms, emphasize that they have been treated fairly by their firms and have not suffered because of their family commitments.

\section{THE BOTTOM LINE}

Significantly, all but one of the women indicate that they are happy to have chosen a career in law. A few others qualify their responses. One woman, who has left the practice of law, says that "the stress, workload, personal liabilities and number of hours required to generate a reasonable income were not worth it." Another reflects on the difficulties of practising in a smaller centre where her choices as to type of practice were limited. On the other hand, several state that they enjoy the practice of law more than they thought they would when they graduated.

\section{CONCLUSION}

There are two particularly notable features about the current employment of the women in our class. Of those who started out practising law, only one has left the profession "mid-career" (another, who attended law school as a mature student, has retired). ${ }^{7}$ There does, however, seem to have been a clear movement out of private practice and into 
alternative legal careers. ${ }^{8}$ Some of our classmates, although quite a small minority, are working part-time. The movement to alternative legal careers and to part-time employment is generally related to a desire to balance professional and personal aspects of life, especially for those women with young children. For the women who remain in private practice, the desire to achieve such a balance is equally important.

Two somewhat conflicting perspectives are apparent. Those in the majority of the class of 1979 do feel that they have achieved a balance between professional and private lives, after some re-thinking of priorities, and for many, re-defining of the concept of success. One classmate pleads the need for such a balance with particular eloquence:

Lastly, I would wish that many of my hard-working, overachicving colleagues would be kinder to themselves. Women lawyers in particular appear to have bought into the "superwoman" role. I fear that this will result in many of us suffering heart attacks and other stress-related illness as we approach "midlife". I also wonder whether we are creating desirable role models for our children, especially our female children. Do we really want them to "have it all" at the expense of their health and overall happiness?

On the other hand, some of the members of the class express concern that through making such accommodations women have, to some extent, marginalized themselves in the profession. As a result, the profession generally, and private practice in particular, is not being forced to make the kinds of changes necessary to make women truly equal colleagues. We close with two comments reflecting on the need for further change:

- I think it is significant that very few of my classmates remain in the "larger" firms. Aithough they may be very happy in what they are doing outside of the larger firms - presumably in an atmosphere and environment with values and attitudes more similar to their own - I think it is a shame that the larger and more established firms have been and, in my view anyway, continue to be generally unaccommodating, inflexible and unprogressive in their attitudes and practices.

- As I look at the profession today as compared to 1979 I cannot help but feel that the profession has in fact adapted to women and not that women have conquered the profession. I sce a lot of women in the corporate offices of municipalities, banks, etc., in matrimonial practice, conveyancing, small litigation practices, etc. I don't see them being recognized as having major motor vehicle litigation expertise, or property and development lawyers' expertise. Put simply, I still don't see them advising the major boardrooms of this country and I certainly don't see them sitting on the major corporate boards in this country.

к. Transitions, supra, note 4 at 2, 19-20 and Encoumering Barriers, supra, note 3 at 7-8, both reported that women were disproportionately represented in government employment and under-represented in private practice. 